\title{
Nanoparticle-mediated catalase delivery protects human neurons from oxidative stress
}

\author{
A Singhal ${ }^{1}$, VB Morris ${ }^{2}$, V Labhasetwar ${ }^{2}$ and A Ghorpade ${ }^{*, 1}$
}

Several neurodegenerative diseases and brain injury involve reactive oxygen species and implicate oxidative stress in disease mechanisms. Hydrogen peroxide $\left(\mathrm{H}_{2} \mathrm{O}_{2}\right)$ formation due to mitochondrial superoxide leakage perpetuates oxidative stress in neuronal injury. Catalase, an $\mathrm{H}_{2} \mathrm{O}_{2}$-degrading enzyme, thus remains an important antioxidant therapy target. However, catalase therapy is restricted by its labile nature and inadequate delivery. Here, a nanotechnology approach was evaluated using catalase-loaded, poly(lactic co-glycolic acid) nanoparticles (NPs) in human neuronal protection against oxidative damage. This study showed highly efficient catalase encapsulation capable of retaining $99 \%$ enzymatic activity. NPs released catalase rapidly, and antioxidant activity was sustained for over a month. NP uptake in human neurons was rapid and nontoxic. Although human neurons were highly sensitive to $\mathrm{H}_{2} \mathrm{O}_{2}$, NP-mediated catalase delivery successfully protected cultured neurons from $\mathrm{H}_{2} \mathrm{O}_{2}$-induced oxidative stress. Catalase-loaded NPs significantly reduced $\mathrm{H}_{2} \mathrm{O}_{2}$-induced protein oxidation, DNA damage, mitochondrial membrane transition pore opening and loss of cell membrane integrity and restored neuronal morphology, neurite network and microtubule-associated protein-2 levels. Further, catalase-loaded NPs improved neuronal recovery from $\mathrm{H}_{2} \mathrm{O}_{2}$ pre-exposure better than free catalase, suggesting possible applications in ameliorating stroke-relevant oxidative stress. Brain targeting of catalase-loaded NPs may find wide therapeutic applications for oxidative stress-associated acute and chronic neurodegenerative disorders.

Cell Death and Disease (2013) 4, e903; doi:10.1038/cddis.2013.362; published online 7 November 2013

Subject Category: Neuroscience

Stroke is the fourth leading cause of death, with approximately 130000 deaths each year, following heart disease and cancer, and is the most common cause of adult disability in the United States (US). ${ }^{1}$ In the majority of all US stroke cases (87\%), occlusion of a cerebral blood vessel with blood clots obstructs blood flow to the central nervous system (CNS) and decreases the availability of oxygen and glucose abruptly, leading to pathological permeability of the blood-brain barrier (BBB) and brain injury, clinically known as cerebral ischemia. ${ }^{1}$ During normal conditions, a balance between the formation and clearance of highly reactive free radical species is maintained in living organisms. However, disruption of this homeostasis during stroke and chronic inflammation leads to oxidative stress and severe pathophysiological conditions. ${ }^{2}$

Oxidative stress continues to attract significant interest because it is a common molecular basis in a variety of human neuropathologies in acute hypoxia-ischemia/reperfusion as well as in chronic neurodegenerative diseases such as Alzheimer's disease, Parkinson's disease and HIV-1-associated neurocognitive disorders (HAND).$^{3,4}$ The CNS is particularly susceptible to oxidative stress, mainly because the brain is rich in polyunsaturated fatty acids, accumulates redox metal ions, consumes large amounts of oxygen, is relatively low in antioxidants and is composed largely of nonmitotic, highly differentiated cells that are hard to replace once damaged. $^{2}$ As reactive oxygen species (ROS) are the fundamental mediators of inflammation and neurotoxicity in ischemia/reperfusion injury, ${ }^{5}$ enzymes capable of detoxifying ROS, such as the superoxide dismutase (SOD) family [convert superoxide anion to hydrogen peroxide $\left(\mathrm{H}_{2} \mathrm{O}_{2}\right)$ ], catalase and glutathione peroxidase (convert $\mathrm{H}_{2} \mathrm{O}_{2}$ to water), have been championed as potential antioxidant drugs. Among various ROS products, $\mathrm{H}_{2} \mathrm{O}_{2}$ represents a key target for interventions as it is neither a radical nor an ion, and therefore readily crosses the cell membrane and affects cellular structures distant from its origin. There is no substitute for catalase because SOD is only effective in catabolizing superoxide anion, and not $\mathrm{H}_{2} \mathrm{O}_{2}$. Mechanistically, catalase is

\footnotetext{
${ }^{1}$ Department of Cell Biology and Anatomy, University of North Texas Health Science Center, Fort Worth, TX, USA and ${ }^{2}$ Department of Biomedical Engineering/ND-20, Lerner Research Institute, Cleveland Clinic, 9500 Euclid Avenue, Cleveland, OH, USA

${ }^{*}$ Corresponding author: A Ghorpade, Department of Cell Biology and Anatomy, University of North Texas Health Science Center, 3500 Camp Bowie Blvd, RES 202, Fort Worth, TX 76107, USA. Tel: +1 (817) 735 2048; Fax: +1 (817) 735 2610; E-mail: Anuja.Ghorpade@ unthsc.edu

Keywords: catalase; PLGA nanoparticles; human neurons; neuroprotection; oxidative stress; hydrogen peroxide

Abbreviations: BBB, blood-brain barrier; BSA, bovine serum albumin; Calcein-AM, acetomethoxy derivative of calcein; $\mathrm{CNS}$, central nervous system; $\mathrm{CoCl}_{2}$, cobalt chloride; DAPI, 4',6-diamidino-2-phenylindole; DMT, dimethyl ester; dsDNA ELISA, double-stranded DNA fragmentation enzyme-linked immunosorbant assay; FDA, Food and Drug Administration; GFAP, glial fibrillary acidic protein; $\mathrm{H}_{2} \mathrm{O}_{2}$, hydrogen peroxide; HAND, HIV-1-associated neurocognitive disorders; HBSS, Hank's buffered salt solution; LDH, lactate dehydrogenase; MAP-2, microtubule-associated protein 2; mPTP, mitochondrial membrane permeability transition pore; MTT, (3-[4,5dimethylthiazol-2-yl]-2,5-diphenyltetrazolium bromide); Nano-CAT, catalase-loaded nanoparticles; Nano-CON, control nanoparticles; Nano-coumarin, coumarin-6loaded nanoparticles; NPs, nanoparticles; PLGA, poly(lactic co-glycolic acid); PVA, polyvinyl alcohol; ROS, reactive oxygen species; RSA, rat serum albumin; S.E.M., standard error of mean; SOD, superoxide dismutase

Received 07.6.13; revised 13.8.13; accepted 14.8.13; Edited by A Verkhratsky
} 
also more effective than glutathione peroxidase in neurons ${ }^{6-8}$ and may be an alternate source for oxygen, perhaps assisting in neuroprotection during hypoxic conditions. ${ }^{9-11}$ Therefore, the catalase enzyme has generated intense interest as an antioxidant therapy. However, a short half-life, poor cellular uptake and inability to safely and efficiently deliver catalase into the CNS significantly restrict its therapeutic use. ${ }^{12}$

To address these issues, various delivery methods have been investigated, including polyethylene glycosylation and lecithinization, to improve the circulation half-life ${ }^{13}$ or enzyme fusion with cell membrane-penetrating peptides to increase BBB permeability. ${ }^{14}$ However, each of these approaches was rejected for pharmacological use due to enzyme inactivation, ${ }^{15}$ poor enzyme uptake by neuronal cells ${ }^{16}$ and anaphylactic responses. ${ }^{17}$ Therefore, it becomes a priority to design a delivery system that not only protects catalase from degradation in the biological milieu but also delivers it across the BBB to the site of therapeutic action, such as an ischemic zone or focus of inflammation, while also facilitating cellular entry. In our previous report, active SOD enzyme was delivered across the BBB in an ischemic middle cerebral arterial occlusion rat stroke model using the biocompatible and Food and Drug Administration (FDA)-approved poly(lactic co-glycolic acid) (PLGA) nanoparticles (NPS). ${ }^{18}$ Herein, the catalase enzyme was encapsulated with PLGA NPs (Nano-CAT) and evaluated for neuroprotection against $\mathrm{H}_{2} \mathrm{O}_{2}$-induced cytotoxicity in primary human neurons.

\section{Results}

Formulation and neuronal uptake of NPs. The catalaseloaded NPs' (Nano-CAT) average size was $280 \mathrm{~nm}$ with a polydispersity of 0.034 , suggesting uniformity of the particle size distribution (Figure 1a). The average zeta potential of NPs was $-20.01 \pm 0.85 \mathrm{mV}(n=3)$. Control nanoparticles (Nano-CON) loaded with rat serum albumin (RSA) had physical properties parallel to those of Nano-CAT. The encapsulation efficiency of catalase was approximately $99 \pm 0.03 \% \quad(n=4)$ and each $\mathrm{mg}$ of Nano-CAT contains approximately $87 \mu \mathrm{g}$ or $307 \mathrm{U}$ of catalase activity. Catalase release and enzyme activity were detected within $1 \mathrm{~h}$ $(0.319 \pm 0.07 \mathrm{U} / \mathrm{mg}$ of Nano-CAT); these increased with time, reaching $2.0 \pm 0.02 \mathrm{U} / \mathrm{mg}$ at $24 \mathrm{~h}$ (Figure $1 \mathrm{~b}$ ). Importantly, Nano-CAT retained catalase activity of $24.2 \pm 1.3 \mathrm{U} / \mathrm{mg}$, which was released continuously over a minimum of 1 month (Figure 1c). As NP encapsulation preserved catalase integrity and extended the release of active enzyme, the study of cellular uptake and possible cytotoxicity in cultured primary human neurons were warranted. Human neuron cells treated with PLGA NP loaded with coumarin-6, a fluorescent dye (Nano-coumarin), ${ }^{19}$ demonstrated green fluorescence within $30 \mathrm{~min}$, which continued to increase over $6 \mathrm{~h}$ as opposed to the untreated control (Figure 1d). Cytotoxicity, as measured by the metabolic activity assay (Figure 1e), was low as neither Nano-CAT nor Nano-CON altered cell viability between the concentrations of $50-400 \mu \mathrm{g}$ $\mathrm{NP} / \mathrm{ml}$. These formulations showed effective delivery and were non-toxic, and thus were used for further studies.

$\mathrm{H}_{2} \mathrm{O}_{2}$-mediated toxicity in cultured primary human neurons. The kinetics of $\mathrm{H}_{2} \mathrm{O}_{2}$-mediated cytotoxicity was studied to determine the potential interventional window of neuronal recovery and protection. In such, neuronal cultures were treated with $\mathrm{H}_{2} \mathrm{O}_{2}(12.5-100 \mu \mathrm{M})$ for 3-24h. As shown
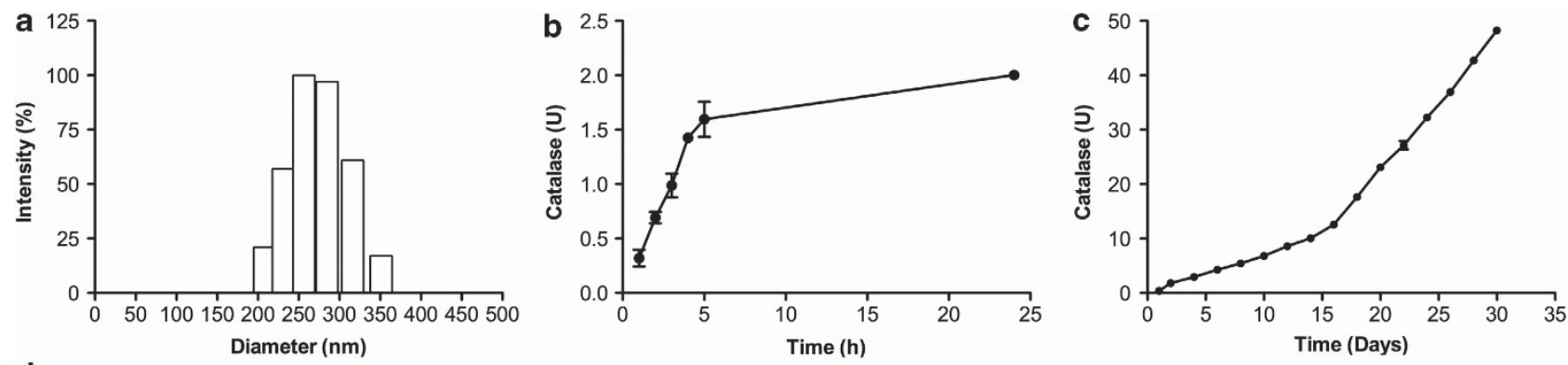

d
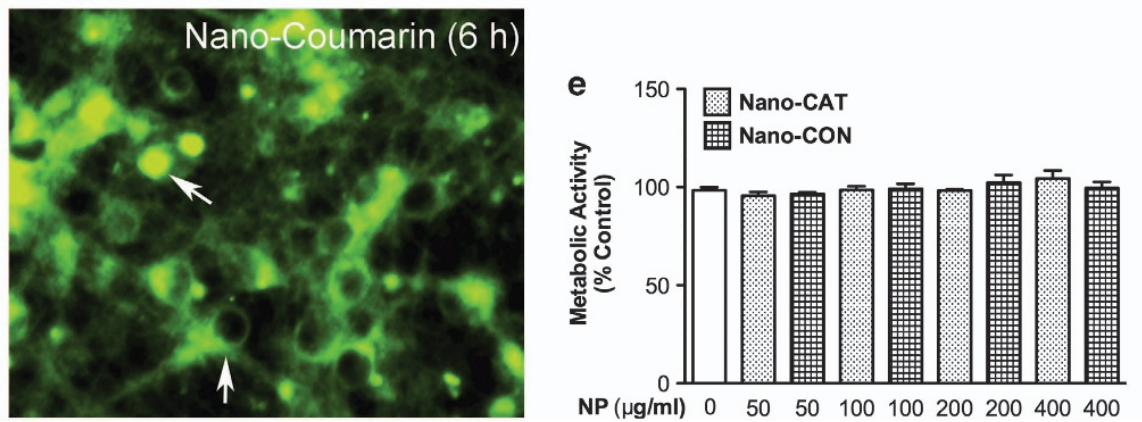

Figure 1 Characterization of Nano-CAT and uptake by neurons. Particle size was determined by dynamic light scattering demonstrating particle size uniformity (a) Catalase released from NPs was quantified by measuring the enzyme activity within $24 \mathrm{~h}$ (b) or for up to 30 days (c). Fluorescent micrograph of neurons treated with $200 \mu \mathrm{g} / \mathrm{ml}$ Nano-coumarin (green) for $30 \mathrm{~min}$ or for $6 \mathrm{~h}$ demonstrating a rapid and time-dependent increase of NP uptake as compared with vehicle control shown in the inset (d). Lack of cytotoxicity of nanoformulations for human neurons was confirmed by the MTT assay (e). Data are mean \pm S.E.M. of triplicates and representative of three biological replicates. Scale bar $=20 \mu \mathrm{m}$ 
by metabolic activity, cell viability was lost in a dosedependent manner from $12.5 \mu \mathrm{M}$ of $\mathrm{H}_{2} \mathrm{O}_{2}$ to $100 \mu \mathrm{M}$ in $6 \mathrm{~h}$ (Figure 2a). With just over $60 \pm 1 \%$ viability, $50 \mu \mathrm{M} \mathrm{H}_{2} \mathrm{O}_{2}$ was selected for further experiments. $\mathrm{H}_{2} \mathrm{O}_{2}$-induced toxicity was also time-dependent. Exposure to $50 \mu \mathrm{M} \mathrm{H}_{2} \mathrm{O}_{2}$ significantly reduced the cell viability after $3 \mathrm{~h}(80.1 \pm 4.7 \%, P<0.001)$, which continued to decrease with time through $12 \mathrm{~h}(51.28 \pm$ $0.8 \%, P<0.001)$. Further incubation up to $24 \mathrm{~h}$ did not change the metabolic activity significantly (49.1 $\pm 1.0 \%$, $P<0.001$; Figure 2b) compared with $12 \mathrm{~h}$. Next, cell membrane integrity was assayed. As loss of plasma membrane integrity is a 'point of no recovery' phenomenon, therapeutic strategies will be effective only if given before integrity loss. As evident by lactate dehydrogenase (LDH) activity assay (Figure 2c), neuronal plasma membrane integrity loss was detected after $12 \mathrm{~h}$ of $\mathrm{H}_{2} \mathrm{O}_{2}$ exposure, but remained intact through $6 \mathrm{~h}$. Thus, the majority of neurons were recoverable prior to $6 \mathrm{~h}$ of $50 \mu \mathrm{M} \mathrm{H}_{2} \mathrm{O}_{2}$ exposure, representing the interventional window, and possibly an extended interventional window from 6 through to $12 \mathrm{~h}$.

Nano-CAT protects neurons from $\mathrm{H}_{2} \mathrm{O}_{2}$-mediated cytotoxicity. To determine whether catalase could be delivered at effective doses sufficient to protect neurons from $\mathrm{H}_{2} \mathrm{O}_{2}$-mediated toxicity, neurons were treated with $\mathrm{H}_{2} \mathrm{O}_{2}$ $(50 \mu \mathrm{M})$ and/or $50-200 \mu \mathrm{g} / \mathrm{ml}$ of Nano-CAT or Nano-CON for $6 \mathrm{~h}$. $\mathrm{H}_{2} \mathrm{O}_{2}$-treatment of neurons caused significant loss of cell viability as depicted by metabolic assay (Figure $2 \mathrm{~d}$, $P<0.001)$. However, as compared with $\mathrm{H}_{2} \mathrm{O}_{2}$-alone, simultaneous treatment of Nano-CAT $(50-200 \mu \mathrm{g} / \mathrm{ml})$ preserved cell viability in a dose-dependent manner (Figure $2 \mathrm{~d}$, $P<0.001)$. Concurrently, $\mathrm{H}_{2} \mathrm{O}_{2}$-treated neurons also treated with the highest dose of Nano-CON showed cell viability comparable to that of $\mathrm{H}_{2} \mathrm{O}_{2}$-alone. Interestingly, $200 \mu \mathrm{g} / \mathrm{ml}$ of Nano-CAT showed maximum protection from $\mathrm{H}_{2} \mathrm{O}_{2}$-toxicity and no significant difference in cell survival from untreated control. Therefore, $200 \mu \mathrm{g} / \mathrm{ml}$ of Nano-CAT was used for further experiments.

Nano-CAT-mediated neuroprotection was also assessed by trypan blue exclusion, LDH activity and apoptosis assays following $24 \mathrm{~h}$ of $\mathrm{H}_{2} \mathrm{O}_{2}$-treatment. Trypan blue dye exclusion is a plasma membrane integrity indicator; the dye is actively excluded from live cells (arrowheads, Figure 3), while it is permeable to dead cells (arrows, Figure 3). The percentage of trypan blue-positive cells increased significantly in $\mathrm{H}_{2} \mathrm{O}_{2}$ treated neurons $(54.5 \pm 3.5 \%, P<0.001$, Figures $3 \mathrm{~d}$ and $\mathrm{g})$ as compared with untreated control (10.2 $\pm 2.4 \%$, Figures $3 \mathrm{a}$ and $\mathrm{g}$ ). Nano-CAT treatment significantly brought back the percentage of trypan blue-positive cells in $\mathrm{H}_{2} \mathrm{O}_{2}$-treated cells to baseline levels $(10.8 \pm 3.5 \%, P<0.001$, Figures $3 e$ and g). Neither Nano-CAT nor Nano-CON-alone altered trypan blue exclusion percentages compared with untreated control (Figures 3b, $\mathrm{c}$ and $\mathrm{g}$ ), and Nano-CON failed to protect from $\mathrm{H}_{2} \mathrm{O}_{2}$-toxicity $(53.1 \pm 6.0 \%$, Figures $3 f$ and $\mathrm{g}$ ). The LDH assay showed that $\mathrm{H}_{2} \mathrm{O}_{2}$-treatment for $24 \mathrm{~h}$ compromised the cell membrane integrity (Figure $3 \mathrm{~h}$, $P<0.001$ ); however, simultaneous treatment with NanoCAT abrogated LDH release $(P<0.001$, Figure $3 \mathrm{~h})$. The quantitative assessment of neuronal apoptosis measured by double-stranded DNA fragmentation enzyme-linked immunosorbant assay (dsDNA ELISA) showed that $\mathrm{H}_{2} \mathrm{O}_{2}$ treatment for $24 \mathrm{~h}$ significantly increased DNA damage (Figure 3i, $P<0.001$ ). Concurrent with other assays, $\mathrm{H}_{2} \mathrm{O}_{2}$ induced DNA damage decreased significantly with NanoCAT treatment $(P<0.001$, Figure $3 \mathrm{i})$, while Nano-CON showed no protective effects.

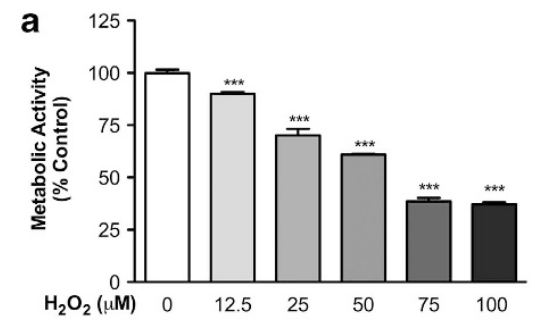

b
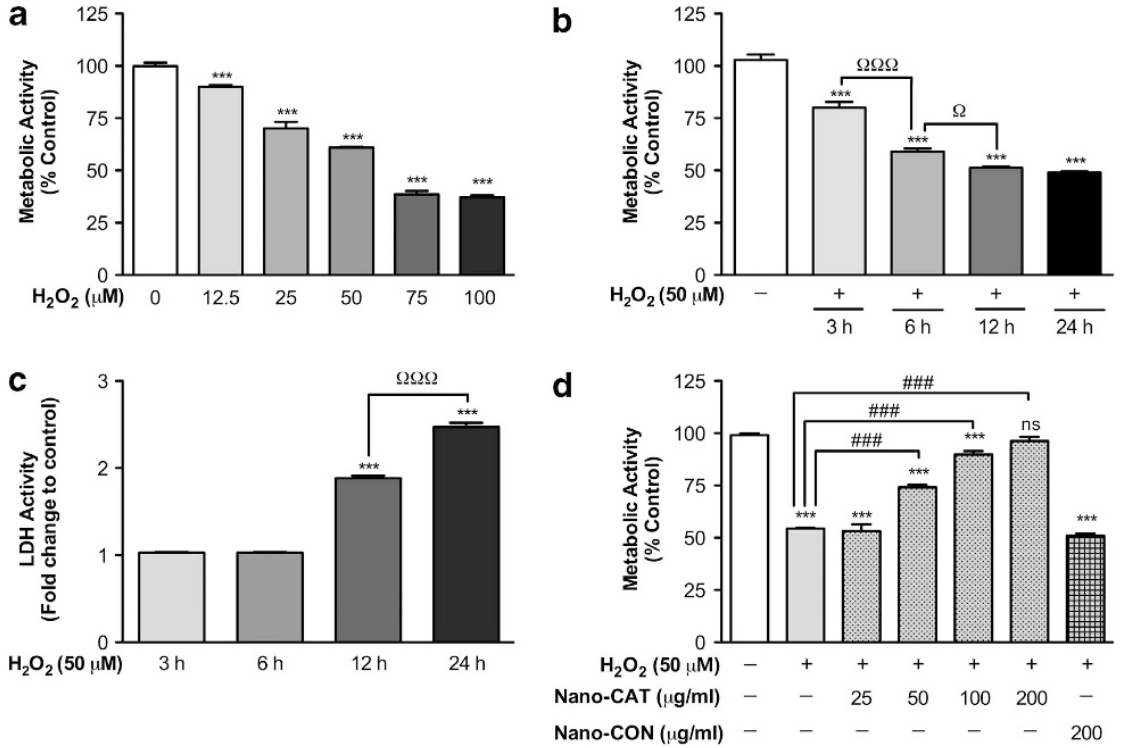

Figure 2 Demonstration of $\mathrm{H}_{2} \mathrm{O}_{2}$-mediated neurotoxicity and Nano-CAT-mediated protection. Primary human neurons were exposed to $\mathrm{H}_{2} \mathrm{O}_{2}$ (12.5-100 $\mu \mathrm{M}$ ) for increasing time points (3-24 h). Metabolic activity was measured by MTT assay and expressed as a percentage of MTT activity (a, $\mathbf{b})$. A dose- and time-dependent decrease in cell viability was observed $(\mathbf{a}, \mathbf{b})$. The cell membrane integrity was measured by LDH assay as fold increase over the respective control (c). Human neurons were exposed to $\mathrm{H}_{2} \mathrm{O}_{2}(50 \mu \mathrm{M})$ with or without Nano-CAT $(50-200 \mu \mathrm{g} / \mathrm{ml})$ or Nano-CON $(200 \mu \mathrm{g} / \mathrm{ml})(\mathrm{d})$ Cell survival was analyzed after $6 \mathrm{~h}$ by MTT assay as expressed as a percentage of MTT activity (d). Data are mean \pm S.E.M. of a minimum of triplicates and representative of at least three biological replicates. Symbols indicate the relative level of significance compared with vehicle control ( $\left.{ }^{* * *} P<0.001\right)$ or with the $\mathrm{H}_{2} \mathrm{O}_{2}$-treatment group $\left({ }^{\Omega} \mathrm{P}<0.05\right.$ and $\left.{ }^{\Omega \Omega \Omega} \mathrm{P}<0.001\right)$ or with $\mathrm{H}_{2} \mathrm{O}_{2}$ alone (ns, not significant; ${ }^{\# \# \#} P<0.001$ ) 

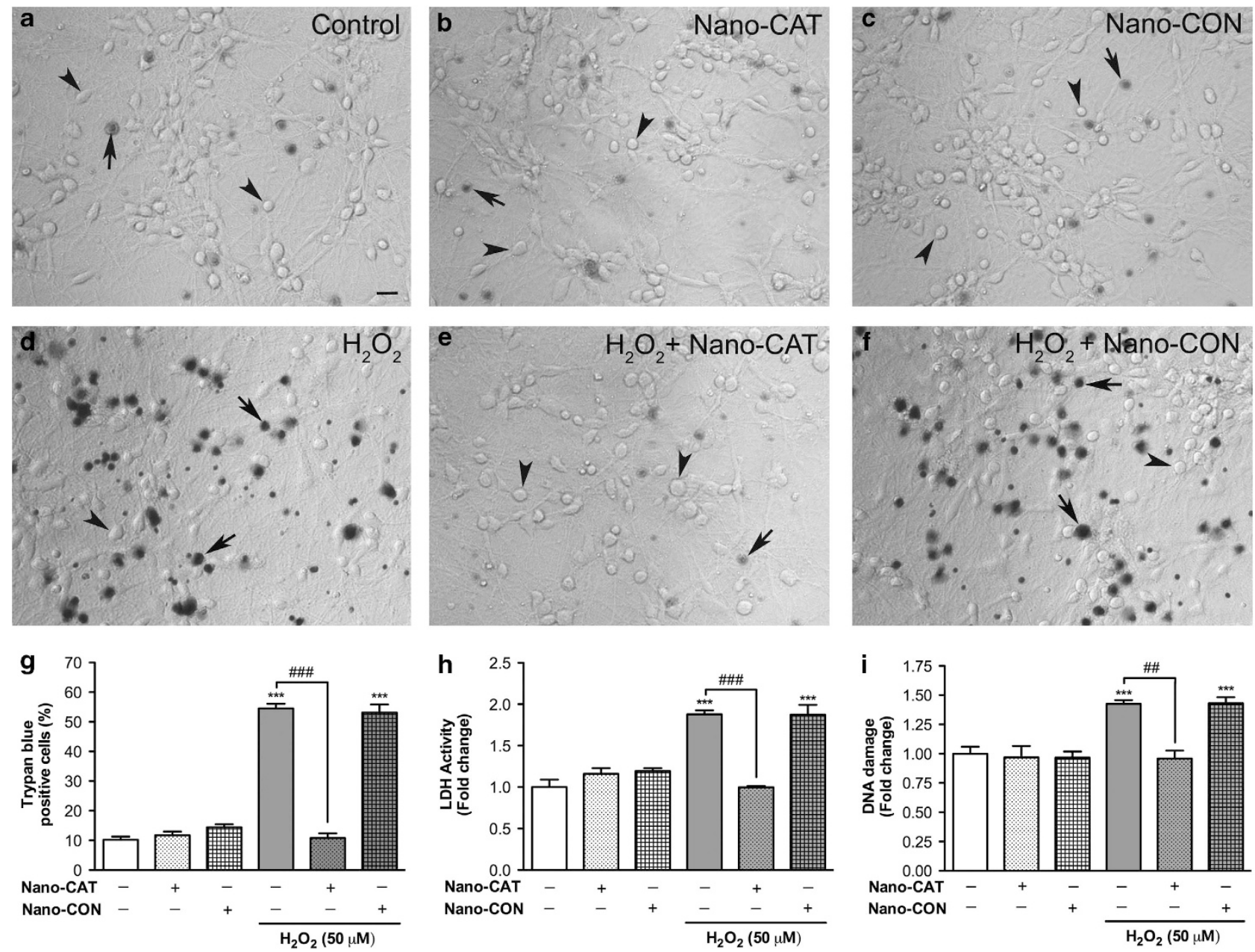

Figure 3 Nanoparticle-mediated catalase delivery protected human neurons from $\mathrm{H}_{2} \mathrm{O}_{2}$-mediated cytotoxicity. Primary cultured human neurons were exposed to $\mathrm{H}_{2} \mathrm{O}_{2}$ $(50 \mu \mathrm{M}, 24 \mathrm{~h})$ with or without $200 \mu \mathrm{g} / \mathrm{ml}$ of Nano-CAT or Nano-CON. Cell survival was assayed using the trypan blue exclusion assay on three biological replicates with each condition in multiple replicates $(\mathbf{a}-\mathbf{g})$. Representative micrographs from five random fields are shown for untreated control (a); NP-alone control, Nano-CAT (b) and Nano-CON (c); $\mathrm{H}_{2} \mathrm{O}_{2}$-alone (d) or with Nano-CAT (e) or with Nano-CON (f). Scale bar $=50 \mu \mathrm{m}$. Trypan blue-positive cells were considered as dead cells (represented by arrow), whereas cells that excluded trypan blue (arrowhead) were counted as live and the percentage of trypan blue-positive cells was calculated (g). Cell membrane integrity was measured after $24 \mathrm{~h}$ of treatment by LDH assay (h). DNA fragmentation was quantified by ELISA to detect neuronal apoptosis (i). Data are presented as mean \pm S.E.M. of triplicates and representative of three biological replicates. Symbols indicate the relative level of the significance compared with vehicle control $\left({ }^{* * *} P<0.001\right)$ or comparisons with $\mathrm{H}_{2} \mathrm{O}_{2}$-alone $\left({ }^{\# \#} \mathrm{P}<0.01\right.$ and $\left.{ }^{\# \#} P<0.001\right)$.

\begin{abstract}
Nano-CAT protects neurons from alteration of cell morphology and microtubule-associated protein-2 (MAP-2) expression. Next, we investigated morphological changes in neurons treated with $\mathrm{H}_{2} \mathrm{O}_{2}$ in the presence or absence of Nano-CAT. Live cell phase-contrast microscopy showed that, compared with controls (Figures $4 \mathrm{a}-\mathrm{c}$ ), $\mathrm{H}_{2} \mathrm{O}_{2}-$ treatment led to characteristic neurite degeneration, cell shrinkage and complete loss of cell body in human neurons (arrows, Figure 4d). However, upon Nano-CAT co-treatment a clear cell body and neurite network were observed, indicating neuronal rescue from $\mathrm{H}_{2} \mathrm{O}_{2}$-induced cell structure damage (arrow heads, Figure 4e). Nano-CON-treated neurons showed characteristic $\mathrm{H}_{2} \mathrm{O}_{2}$-induced cell morphological changes (Figure 4f). Immunofluorescent staining of neuronal cytoskeleton protein MAP-2 was performed. Overall, $\mathrm{H}_{2} \mathrm{O}_{2}$-treated neurons showed a significant decrease in MAP-2-positive cells, with contracted cell bodies and neuronal processes and predominant nuclear staining
\end{abstract}

(blue, 4', 6-diamidino-2-phenylindole (DAPI), arrows, Figure 5d). However, co-treatment with Nano-CAT (Figure 5e) protected neurons from MAP-2 loss, where cells demonstrated normal cell bodies, neurite networks and overall bright MAP-2 staining (arrowheads, Figure 5e). Taken together, Nano-CAT protected human neurons from $\mathrm{H}_{2} \mathrm{O}_{2}$-induced morphological and structural abnormalities.

Nano-CAT facilitates recovery of neurons pre-exposed to oxidative stress. Whether Nano-CAT can attenuate cell death in neurons acutely pre-exposed to high oxidative stress levels was assessed by treating neurons with $\mathrm{H}_{2} \mathrm{O}_{2}$ for $3-24 \mathrm{~h}$, followed by stress removal and subsequent treatment with Nano-CAT, Nano-CON or free catalase enzyme at equivalent units to that of Nano-CAT in suspension. Human neurons showed significant loss of cell viability depending on the time of $\mathrm{H}_{2} \mathrm{O}_{2}$ pre-exposure (Figure 6a). However, Nano-CAT significantly improved cell viability in neurons 

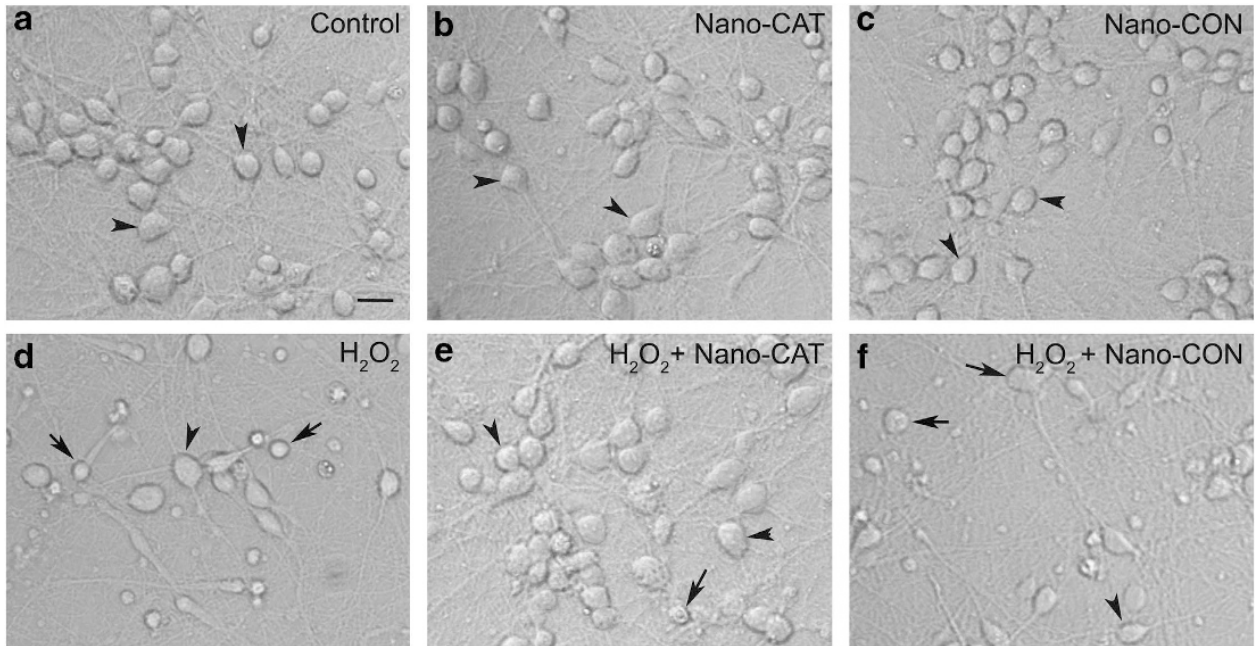

Figure 4 Nano-CAT protected primary human neurons from $\mathrm{H}_{2} \mathrm{O}_{2}$-mediated alteration of cell morphology. Human neurons challenged with $50 \mu \mathrm{M} \mathrm{H}_{2} \mathrm{O}_{2}$-alone (d) or with $200 \mu \mathrm{g} / \mathrm{ml}$ Nano-CAT (e) or Nano-CON (f) for $24 \mathrm{~h}$ were imaged for analysis of cell morphology by live-cell phase-contrast imaging and compared with untreated neurons (a). Neurons treated with Nano-CAT (b) or Nano-CON (c) were used as NP-alone control. The arrow represents the loss of neurite and shrunken cell body, whereas the arrowhead shows normal cell morphology. Images are representative of six random fields and four biological replicates. Scale bar $=50 \mu \mathrm{m}$
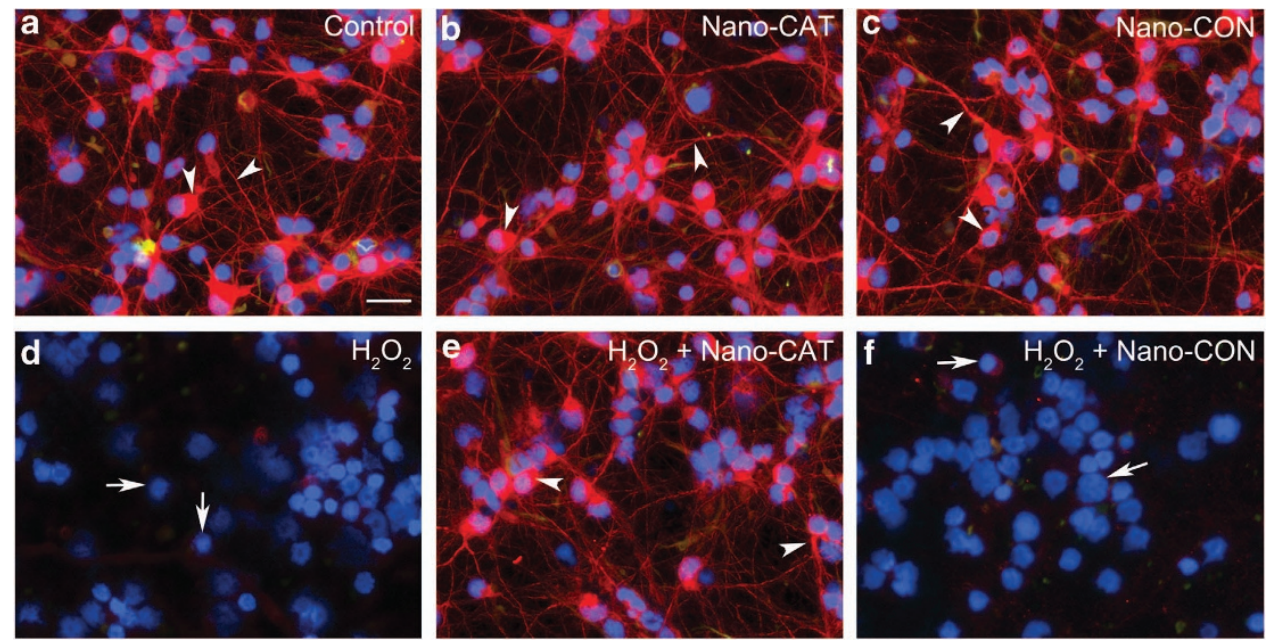

Figure 5 Nano-CAT protected human neurons from $\mathrm{H}_{2} \mathrm{O}_{2}$-induced downregulation of MAP-2 expression. Human neurons challenged with $50 \mu \mathrm{M} \mathrm{H}_{2} \mathrm{O}_{2}$-alone (d) or with $200 \mu \mathrm{g} / \mathrm{ml}$ Nano-CAT (e) or Nano-CON (f) for $24 \mathrm{~h}$ were stained for MAP-2 and compared with untreated neurons (a). Neurons treated with Nano-CAT (b) or Nano-CON (c) were used as NP-alone control. Immunostaining micrographs (a-f) show MAP-2 staining (red; neuronal marker), GFAP (green, astrocyte marker) and DAPI (blue, nuclei). The arrow represents loss of MAP-2, neurite network or fragmented nuclei. The arrowhead represents MAP-2-enriched neurons. Images are representative of five random fields of three biological replicates. Scale bar $=50 \mu \mathrm{m}$

pre-exposed for $3 \mathrm{~h}(89.7 \pm 3.6 \%)$ compared with $\mathrm{H}_{2} \mathrm{O}_{2}$-alone $(72.9 \pm 3.1 \%)$ as well as for $24 \mathrm{~h}(64.1 \pm 4.6 \%)$ compared with $\mathrm{H}_{2} \mathrm{O}_{2}$-alone $(46.2 \pm 2.9 \%$ ) (Figures $6 \mathrm{a}$ and $\mathrm{b}$ ). Further, as compared with catalase enzyme in solution, NanoCAT-mediated neuronal recovery was significantly higher $(13 \%, P<0.001$, Figure $6 \mathrm{~b})$ after $24 \mathrm{~h}$ pre-exposure treatment. Nano-CON offered no protection, showing toxicity comparable to $\mathrm{H}_{2} \mathrm{O}_{2}$-alone at all time points.

Nano-CAT protects neurons from $\mathrm{H}_{2} \mathrm{O}_{2}$-mediated protein oxidation and mitochondrial membrane permeability transition pore (mPTP) opening. Next, the protective effect of Nano-CAT was investigated against the direct oxidative action of $\mathrm{H}_{2} \mathrm{O}_{2}$, an important $\mathrm{H}_{2} \mathrm{O}_{2}$-induced cytotoxic mechanism. Changes in protein carbonylation were assayed as a measure of protein oxidation in $\mathrm{H}_{2} \mathrm{O}_{2}-$ treated neurons in the presence or absence of Nano-CAT. Control untreated, Nano-CAT- and Nano-CON-alonetreated human neurons exhibited very low levels of carbonyls (Figure 7a). However, protein carbonyls increased significantly following $\mathrm{H}_{2} \mathrm{O}_{2}$-treatment, indicating oxidative damage $(P<0.001$, Figure 7a). However, Nano-CAT co-treatment significantly reduced protein oxidation, showing the effective catalase delivery and protection from direct oxidation of proteins. Nano-CON failed to protect against protein carbonyl accumulation (Figure 7a), and thus protection was exclusively mediated by catalase delivery. 

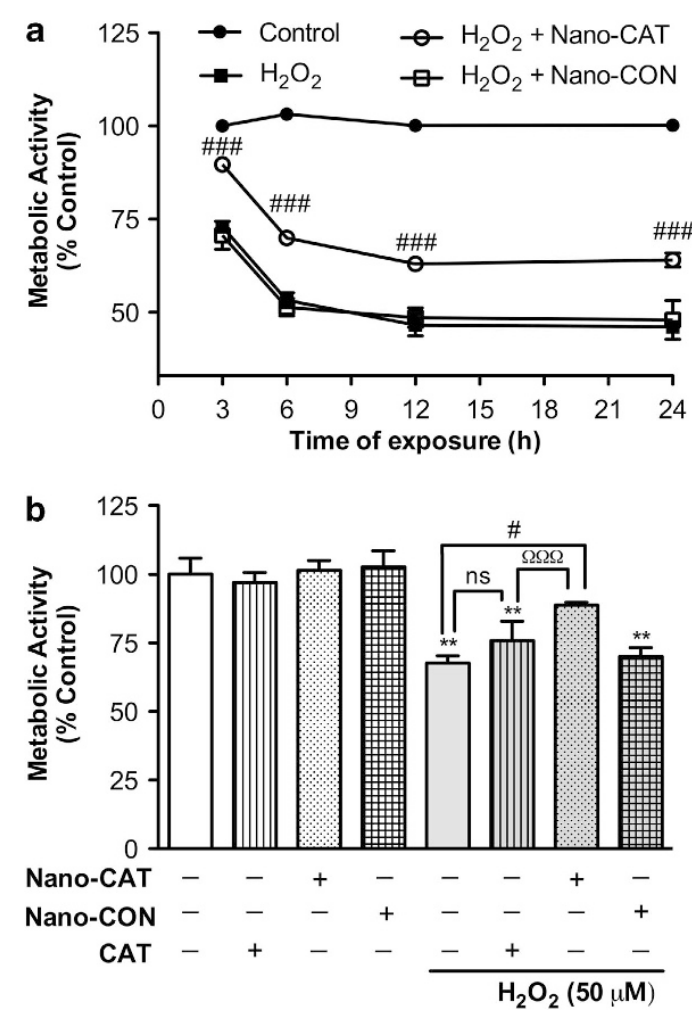

Figure 6 Nano-CAT facilitated recovery of human neurons from oxidative stress. Neurons were pre-exposed to $\mathrm{H}_{2} \mathrm{O}_{2}(50 \mu \mathrm{M}, 3-24 \mathrm{~h})$ followed by washing and treatment with or without catalase enzyme $(200 \mu \mathrm{g} / \mathrm{ml})$, Nano-CAT or NanoCON $(200 \mu \mathrm{g} / \mathrm{ml})$. After $6 \mathrm{~h}$, cell viability was measured by MTT-assay. Pre-exposure to $\mathrm{H}_{2} \mathrm{O}_{2}$ induced a time-dependent cytotoxicity in neurons (a). As compared with free catalase enzyme in solution, Nano-CAT significantly recovered neurons from $\mathrm{H}_{2} \mathrm{O}_{2}$-toxicity $(\mathbf{a}, \mathbf{b})$. Data are presented as mean \pm S.E.M. of triplicates and representative of three biological replicates. Symbols indicate statistical significance compared with untreated control ( $\left.{ }^{*} P<0.01\right)$ or with $\mathrm{H}_{2} \mathrm{O}_{2}$ alone $\left({ }^{\#} P<0.05\right.$ and $\left.{ }^{\# \#} P<0.001\right)$ or $\mathrm{H}_{2} \mathrm{O}_{2}$ with free catalase enzyme $\left({ }^{\Omega \Omega \Omega} P<0.001\right)$

Finally, as a measure of mitochondrial health, $\mathrm{H}_{2} \mathrm{O}_{2}$ induction of MPTP opening in cultured primary human neurons was assessed by the acetomethoxy derivative of calcein (calcein-AM) and the cobalt chloride $\left(\mathrm{CoCl}_{2}\right)$ assay. The mPTP opening increased in $\mathrm{H}_{2} \mathrm{O}_{2}$-treated neurons, as evidenced by loss of green/yellow fluorescence (arrows, Figure 7c). However, in contrast to Nano-CON (Figure 7e), co-treatment with Nano-CAT inhibited the mPTP opening (arrowheads, Figure 7d).

\section{Discussion}

Considering that oxidative stress is a hallmark feature in many different types of neuropathology, effective therapeutic interventions critically lack measures for the various neurodegenerative disorders mediated by such mechanisms. Herein, we assessed a nanotechnology approach utilizing catalaseloaded PLGA NPs, which effectively delivered antioxidant therapy to human neurons. The hypersensitive nature of neurons toward oxidative stress, as demonstrated in previous reports, ${ }^{6,20}$ was reflected in our in vitro cellular model at levels measured following ischemia in rats $\left(25-100 \mu \mathrm{M} \mathrm{H}_{2} \mathrm{O}_{2}\right)$. $^{21,22}$ This may be due to high levels of polyunsaturated fatty acids in
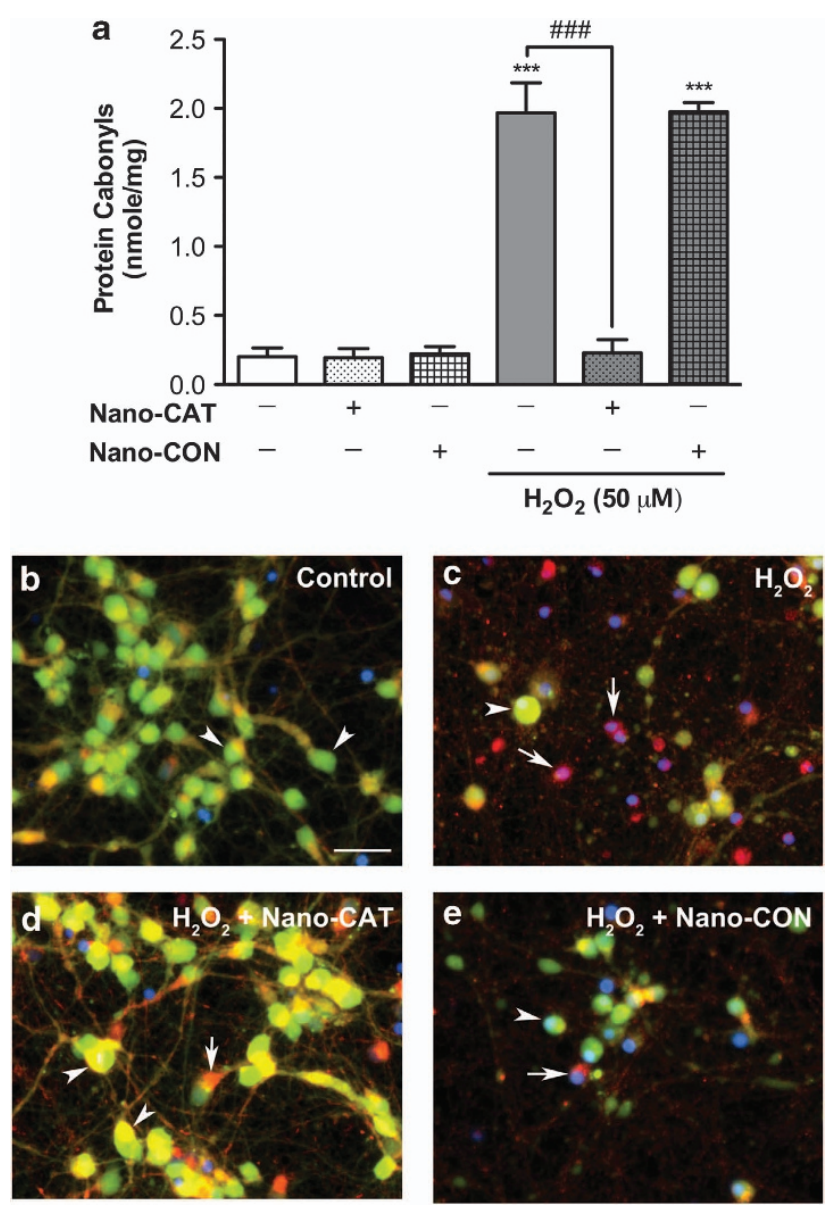

Figure 7 Nano-CAT inhibited the $\mathrm{H}_{2} \mathrm{O}_{2}$-induced protein oxidation and mPTP opening. Protein carbonyls were measured in cell lysates prepared from neurons treated with $\mathrm{H}_{2} \mathrm{O}_{2}(50 \mu \mathrm{M}, 24 \mathrm{~h})$ with or without $200 \mu \mathrm{g} / \mathrm{ml}$ of Nano-CAT or Nano$\operatorname{CON}(\mathbf{a})$. Data are presented as mean \pm S.E.M. of triplicates and representative of two biological replicates. Symbols indicate statistical significance compared to

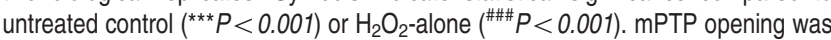
monitored using Calcein/ $\mathrm{CoCl}_{2}$ assay (b-e). Calcein (green fluorescence) colocalized with MitoTraker (red) represents closed MPTP (yellow; b, arrowhead), while loss of mitochondrial green fluorescence represents opening of MPTP (red; c, e, arrow). Control shows bright calcein fluorescence (green/yellow) indicating intact mitochondria (b). Neurons treated with $\mathrm{H}_{2} \mathrm{O}_{2}$ displayed a significant decrease in calcein fluorescence suggesting MPTP opening and quenching of calcein fluorescence by cytoplasmic $\mathrm{CoCl}_{2}$ (c). Simultaneous treatment of Nano-CAT (d) but not Nano-CON (e) significantly blocked the decrease in calcein fluorescence caused by $\mathrm{H}_{2} \mathrm{O}_{2}$ suggesting opening of mPTP inhibition. Scale bar $=50 \mu \mathrm{m}$

the brain, limited neuronal antioxidant capacity or a necessity for metabolite and catalase support from astrocytes. ${ }^{8,23,24}$ The primary human neuron cultures used in this study were at least $90 \%$ pure, as measured by MAP-2 and glial fibrillary acidic protein (GFAP) staining, reflecting an environment relatively devoid of astrocytic protection or influence. In this study, oxidative stress eventually led to an irreversible cascade toward neuronal death in a time- and dosedependant manner. However, upon therapeutic intervention with catalase-loaded nanoparticles, significant neuroprotection as well as neuronal recovery from oxidative stress was observed. Nano-CAT protected human neurons from $\mathrm{H}_{2} \mathrm{O}_{2}$-induced cellular protein oxidation, DNA damage, mPTP 
opening and loss of neuronal cytoskeleton structure and plasma membrane integrity.

Alternate neuroprotective agents have generated great interest, despite the availability of thrombolytic therapy (t-PA) for stroke treatment due to reperfusion injury and risk of hemorrhage. $^{12}$ Gene therapy strategies for expressing neuroprotective proteins in the brain have had severe limitations, resulting in failures due to ineffective delivery of plasmid to the nucleus of targeted cell or tissue ${ }^{25}$ or due to safety concerns. In fact, deaths during human trials led to a moratorium on viral vectors for gene therapy. ${ }^{26-28}$ In comparison, exogenous enzymatic supplementation appears naturally relevant during the process of acute ischemic stroke. During stroke, ROS generation is rapid and cellular survival responses are compromised. The protective transcriptional activation of detoxification enzymes is delayed in the remaining live cells under diminished oxygen and glucose supplies. Thus, effective and timely delivery of detoxification enzymes to the target site is an important priority and a major challenge.

Many multicenter clinical trials of potential neuroprotective agents showed either lack of efficacy or unacceptable side effects, but antioxidant therapy shows promise. ${ }^{29}$ As an antioxidant therapy, catalase has natural advantages including highest turnover rates of any known enzyme, ${ }^{30}$ potential regulatory function, ${ }^{31}$ greater effectiveness than glutathione peroxidase in neurons during oxidative stress ${ }^{6,7}$ and ability to serve as an alternate source for oxygen upon $\mathrm{H}_{2} \mathrm{O}_{2}$ degradation to rescue neurons from hypoxic conditions. ${ }^{9-11}$ Studies have revealed that astrocytes are remarkably resistant to oxidative stress; however, oxidative stress is shown to mediate neurodegeneration in many CNS pathologies, ${ }^{3,4}$ clearly escaping astrocytic attempts to maintain homeostasis during disease. At the time of CNS injury, inactivation of catalase by $\mathrm{H}_{2} \mathrm{O}_{2}$ and a shifting of astrocytic behavior from 'helper cell' to 'inflammatory cell' act to exacerbate neurotoxicity. $^{32,33}$ Therefore, exogenous, extended delivery of active catalase to neurons may be an effective and relevant antioxidant therapy, particularly when astrocyte support fails during ischemia/reperfusion injury. However, because of degradation, inactivation and inability to traverse an intact $\mathrm{BBB},{ }^{12}$ catalase has major hurdles impeding therapeutic use.

Among polymers, PLGA is the only FDA-approved, biodegradable and biocompatible drug delivery carrier available so far. It has been extensively used to deliver many bioactive biomolecules across the BBB and into the CNS. ${ }^{12}$ Encouragingly, our studies show that PLGA encapsulation retained catalase activity for over a month, which would protect the enzyme from inactivation. Further, BBB permeability and sustained release of enzyme make PLGA NPs suitable even after restoration of BBB integrity. First, we investigated the ability of neurons to take up the PLGA formulation. In our model, cultured human neurons showed PLGA NP uptake in a time-dependent manner, probably by endocytosis. ${ }^{34}$ As many cationic polymers and lipids commonly used for drug delivery have toxic effects on cells at higher concentrations, ${ }^{35}$ any possible side effects were also examined. The formulation itself was non-toxic to human neurons at high doses, establishing catalase delivery by PLGA NPs a viable strategy for further investigations.
Although $200 \mu \mathrm{g} / \mathrm{ml}$ of Nano-CAT showed complete protection, $50 \mu \mathrm{g} / \mathrm{ml}$ of Nano-CAT was also effective against $\mathrm{H}_{2} \mathrm{O}_{2}$ toxicity. As treatment with Nano-CON was not effective, catalase activity, rather than the PLGA formulation or NP uptake, was neuroprotective. As Nano-CAT protected neurons from oxidative stress in a dose-dependant manner, one could postulate that Nano-CAT may be delivered into the brain systemically or by direct injection to damaged brain areas to achieve high concentrations without toxicity. Moreover, if necessary, the delivery and distribution of Nano-CAT across the BBB may be increased significantly by surface modifications such as HIV-1-mutated tat-peptide tagging. ${ }^{36}$

One action of neuroprotective agents is limiting acute injury to 'recoverable' neurons in the ischemic penumbra, which are less likely to suffer irreversible injury at early time points compared with neurons in the infarct core ${ }^{29}$ Collateral and residual blood flow can preserve neurons in the penumbral and border areas for as long as $6 \mathrm{~h}$ after an ischemic stroke. ${ }^{29}$ Therefore, attenuation of neuronal death by Nano-CAT in neurons within the first $6 \mathrm{~h}$ has clinical significance. Our data showed that Nano-CAT facilitated the recovery of neurons previously exposed to high levels of oxidative stress (as equivalent to a stroke case), which indicates the potential clinical applicability of Nano-CAT in ischemia for reducing the level of irreversible brain damage. Further, Nano-CAT released significant levels of active catalase enzyme for extended periods of time (at least 30 days, in vitro), which could be remarkably beneficial for recovery/protection of neurons at both the initial site of injury as well as at relatively distant areas of an injured brain challenged by chronic ROS generation due to inflammation. Therefore, nanotechnologybased delivery of catalase could potentially be useful to counteract brain pathological processes, augment compensatory mechanisms and influence the brain regenerative capacities.

Further mechanisms of Nano-CAT-mediated neuroprotection were also investigated. The data show that $\mathrm{H}_{2} \mathrm{O}_{2}$ induced cell membrane integrity loss, which could be the result of lipid peroxidation, alterations in cell membrane proteins, disorganization of intracellular structures and eventually cell death. Oxidative stress also decreased the expression of neuronal cytoskeleton protein MAP-2, which helps in maintenance of the cell body shape and neurite network. However, Nano-CAT not only rescued neurons from cell membrane integrity loss but also preserved MAP-2 expression and overall cell morphology. Further, Nano-CAT reduced $\mathrm{H}_{2} \mathrm{O}_{2}$-mediated protein carbonyl formation and $\mathrm{MPTP}$ opening, an early apoptotic event in neurons, ${ }^{37}$ also dysregulated by hypoxia and glucose deprivation during stroke. ${ }^{38}$

Recently, we began developing a thromboembolic rat stroke model to mimic clinical scenarios. On the basis of our previous report of successful delivery of active SOD enzyme across the BBB in an ischemic middle cerebral arterial occlusion rat stroke model ${ }^{18}$ and the current study, we are keen on assessing the efficacy of combined SOD and catalase-loaded NPs. Whether we can extend the window of t-PA treatment in stroke therapy with effective antioxidant delivery is yet to be determined.

In conclusion, these observations demonstrate that NanoCAT, through active catalase enzyme delivery, protected 
human neurons from $\mathrm{H}_{2} \mathrm{O}_{2}$-mediated cytotoxicity. Nano-CAT protected neurons from oxidative stress by preserving the neuronal structure, mitochondrial health and plasma membrane integrity by reducing the oxidation of crucial cellular proteins, thus inhibiting the apoptotic cascade. Further, NanoCAT facilitated the recovery of human neurons pre-exposed to oxidative stress. This nanotechnology-based delivery of catalase enzyme may have therapeutic applications in limiting the extent of ischemic lesion and in salvaging time for additional clinical interventions in the treatment of cerebral ischemia. This approach alone or along with other treatments may have broader applications for the treatment of other brain diseases/disorders associated with oxidative stress, such as Alzheimer's disease, Parkinson's disease and HAND.

\begin{abstract}
Material and Methods
Formulation of nanoparticles. Nano-CAT was formulated using a double emulsion solvent evaporation method. ${ }^{39}$ Briefly, $81 \mathrm{mg}$ PLGA polymer (inherent viscosity, 0.76-0.94 d//g, copolymer ratio 50:50) (Cupertino, CA, USA) and $9 \mathrm{mg}$ L-tartaric acid dimethyl ester (DMT) (Sigma-Aldrich, St. Louis, MO, USA) were dissolved in $3 \mathrm{ml}$ dichloromethane to form a polymer solution. Polyvinyl alcohol (PVA: average MW $30000-70000 \mathrm{Da}$ ) solution was prepared by slowly adding $5 \mathrm{~g}$ of PVA (Sigma-Aldrich) in $100 \mathrm{ml}$ of water with stirring on a magnetic stir plate. Temperature of the PVA solution was raised to $85-95^{\circ} \mathrm{C}$ to completely dissolve PVA. The PVA solution was cooled to room temperature and then filtered through a $0.22 \mu \mathrm{m}$ syringe filter (MILLEX GP Filter unit, EMD Millipore Corp., Billerica, MA, USA). An aqueous solution of catalase from bovine liver $(8 \mathrm{mg}, 2000-5000 \mathrm{U} / \mathrm{mg})$ and $22 \mathrm{mg}$ of RSA in $300 \mu \mathrm{l}$ of double distilled water (both from Sigma-Aldrich) was first emulsified into the polymer solution by vortexing for 1 min, followed by sonication using a microtip probe sonicator for $2 \mathrm{~min}$ on an ice bath at $55 \mathrm{~W}$ of energy output (XL 2015 Sonicator ultrasonic processor, Misonix Inc., Farmingdale, NY, USA) to form a primary water-in-oil emulsion. RSA provides stability to the encapsulated enzyme from interfacial inactivation, and DMT facilitates the release of encapsulated enzyme from NPs. ${ }^{18}$ The primary emulsion was further emulsified into $18 \mathrm{ml}$ PVA solution first by vortexing and then by sonication as described above. The secondary water-in-oil-in-water emulsion thus formed was stirred overnight on a magnetic stir plate at room temperature followed by stirring in a vacuum desiccator for $1 \mathrm{~h}$ to allow complete removal of the organic solvent. The resultant NPs were then recovered by ultracentrifugation at $30000 \mathrm{rpm}$ for $30 \mathrm{~min}$ at $4{ }^{\circ} \mathrm{C}$ (50Ti Rotor, Beckman Optima LE-80 K: Beckman Instruments, Palo Alto, CA, USA) and washed twice with water to remove PVA and un-encapsulated proteins by resuspending NPs each time in water, followed by sonication and centrifugation as above. The washings were collected and analyzed for the amount of catalase that was not encapsulated in NPs using the amplex red catalase assay kit (Amplex red catalase assay kit, Life Technologies, Eugene, OR, USA). The final suspension was centrifuged at $1500 \mathrm{rpm}$ for $10 \mathrm{~min}$. The supernatants were lyophilized in sterile tubes for 2 days at $-48^{\circ} \mathrm{C}$ and placed in vacuum at $\sim 0.035 \mathrm{mBar}$ (LABCONCO FreeZone 4.5 Liter Freeze Dry Systems, Labconco Corporation, Kansas City, MO, USA). NPs with $30 \mathrm{mg}$ of RSA without
\end{abstract} the enzyme were used as Nano-CON.

Characterization of Nano-CAT. The hydrodynamic diameter and surface charge of NPs were measured by the dynamic light scattering method at an intensity of $300 \mathrm{kHz}$ using a NicompTM 380 DLS (Zeta Potential/ Particle Sizer, Santa Barbara, CA, USA). To measure the size, a suspension of NPs $(0.5 \mathrm{mg} / \mathrm{ml})$ in water was prepared by sonication using a microtip probe sonicator as above for $1 \mathrm{~min}$. The same diluted samples were used to measure the zeta potential of NPs in phase analysis mode and the current mode at a scattering angle of $-14^{\circ}$ using the Nicomp TM.

Catalase loading efficiency in NPs. The loading efficiency of catalase in NPs was assessed by an indirect method: by determining the total amount of catalase added in the formulation and subtracting that which was not encapsulated. Supernatant and washings collected during the preparation of NPs were assayed for enzyme activity. From our previous studies, we demonstrated that quantification of protein loading, as determined by the indirect method, correlates with the total protein released from NPs in vitro. ${ }^{19}$ Activity of the catalase was measured using an Amplex red catalase assay kit as described above.
In vitro release of catalase from NPs and enzyme activity. Catalase release from NPs in vitro was carried out in $0.15 \mathrm{M}$ phosphate buffer saline $(\mathrm{pH} 7.4)$, containing $0.1 \%$ bovine serum albumin (BSA), $0.05 \%$ Tween-20 and $0.05 \%$ sodium azide (all from Sigma-Aldrich) as preservative. The release study was conducted using double diffusion chambers separated by a low-protein binding $0.1 \mu \mathrm{m}$ porosity membrane (Type VV, Millipore Co., Bedford, MA, USA) as described in earlier studies. ${ }^{19}$ Briefly, $6 \mathrm{mg}$ of NPs was dispersed in $7.5 \mathrm{ml}$ of release buffer. The suspension was then vortexed and sonicated in a water bath sonicator (FS-30, Fisher Scientific, Pittsburg, PA, USA) for $10 \mathrm{~min}$. The donor side of each chamber was filled with $2.5 \mathrm{ml}$ of the NPs suspension, and the receiver chamber was filled with an equal volume of release buffer alone. As the hydrodynamic diameter of the NPs is greater than the membrane porosity, only the protein will penetrate through the membrane into the receiver chamber. The chambers were placed on a shaker maintained at $37^{\circ} \mathrm{C}$ and rotating at $110 \mathrm{rpm}$. At different time intervals, the solution from the receiver chambers was removed completely and replaced with a fresh buffer. The collected samples were analyzed for catalase activity using the Amplex red catalase assay kit.

Primary human neuron cultures and treatments. Brain tissues from first- and early second-trimester fetuses were obtained from the Birth Defects Laboratory, University of Washington (Seattle, WA, USA). Human fetal neurons were isolated and cultured, as previously described, ${ }^{40}$ in full compliance with the ethical guidelines of the National Institutes of Health (NIH, Bethesda, MD, USA), the University of Washington and North Texas Health Science Center (Fort Worth, TX, USA). The work described in this article was carried out in accordance with The Code of Ethics of the World Medical Association (Declaration of Helsinki) for experiments involving humans and in accordance with the Uniform Requirements for manuscripts submitted to biomedical journals. The neurons were seeded at a density of $0.1 \times 10^{6} \mathrm{celll} / \mathrm{cm}^{2}$ in poly-D-lysine-coated 48 -well plates or $75 \mathrm{~cm}^{2}$ flasks. After 2 weeks, neuronal cultures were assessed for purity as described previously. ${ }^{37}$ The culture enriched with $>90 \%$ neurons was utilized in neurotoxicity/neuroprotection experiments. All experiments were performed on cell cultures grown for at least 2 weeks in vitro. During treatments, the medium was half exchanged with human neuronal medium supplemented with serum-free B-27 deprived of antioxidants (Life Technologies) added with stabilized $\mathrm{H}_{2} \mathrm{O}_{2}$ in the presence or absence of Nano-CAT or Nano-CON. In experiments utilizing both native catalase and Nano-CAT, $310 \mathrm{U}$ of enzyme, which is equal to $200 \mu \mathrm{g} / \mathrm{ml}$ of Nano-CAT, was added after $\mathrm{H}_{2} \mathrm{O}_{2}$-treatment.

Analysis of NP uptake. To determine the uptake of nanoparticles by human neurons, cell were treated with $200 \mu \mathrm{g} / \mathrm{ml}$ of Nano-coumarin for $30 \mathrm{~min}$ and $6 \mathrm{~h}$. The cells were washed with Hank's buffered salt solution (HBSS, Life Technologies) and live cell imaging was performed using a fluorescent microscope.

Evaluation of cell viability and Nano-CAT toxicity. Cell viability was determined by measuring mitochondrial activity using 3-[4,5-dimethylthiazol-2-yl]2,5-diphenyltetrazolium bromide (MTT), as previously described. ${ }^{41}$ Cell membrane integrity was assayed by LDH assay using a Cytotoxicity Detection Kit according to the manufacturer's instructions (Roche Diagnostics, Indianapolis, IN). The quantitative assessment of apoptosis was achieved by measuring DNA fragmentation using dsDNA ELISA according to the manufacturer's directions (Roche). Cell morphology was observed by live cell imaging and immunostaining. Immunostaining was performed with antibodies to neuronal marker MAP-2 (Millipore, Billerica, MA, USA) and astrocyte marker GFAP (Dako North America, Inc., Carpinteria, CA, USA). Trypan blue exclusion assay was performed using $0.2 \%$ trypan blue in HBSS on cells for $15 \mathrm{~min}$ to observe cell death and cell membrane integrity. Microscope images from at least five random fields of multiple replicates of each experimental condition per experiment were taken at X200 magnification on an Eclipse TE-300 inverted microscope (Nikon Instruments Inc., Melville, NY, USA). Microscopic images presented in this paper show representative data from at least three independent donors. Cells in the microscope images were manually counted and presented as a percentage of trypan blue-positive cells.

Opening of mPTP assay. The cultured primary human neurons were treated with $\mathrm{H}_{2} \mathrm{O}_{2}$ with or without Nano-CAT/Nano-CON for $24 \mathrm{~h}$. The calcein/ $\mathrm{Co}^{2+}$-quenching technique was used to elucidate the subtle phenomena associated with mitochondrial permeability transition leading to programed cell death using the Image-iT LIVE Mitochondrial Transition Pore Assay Kit 
(Life Technologies), as previously described. ${ }^{37}$ Live cells were imaged using a Nikon Eclipse TE-300 microscope with appropriate excitation and emission filters for fluorescein. In closed mPTP condition, the $\mathrm{Co}^{2+}$ quenched the green fluorescence of calcein only outside of the mitochondria; therefore, colocalization of the red color of MitoTracker gives a green/yellow color to the mitochondria. After opening the mPTP, $\mathrm{Co}^{2+}$ quenches the calcein in the mitochondria, which change color from green/yellow fluorescence to red.

Measurement of oxidized cellular protein. Primary human neurons were cultured as an adherent monolayer at a density of $7.5 \times 10^{6}$ cells per flask. Cells were treated with $50 \mu \mathrm{M} \mathrm{H}_{2} \mathrm{O}_{2}$ with/without $200 \mu \mathrm{g} / \mathrm{ml}$ Nano-CAT/Nano-CON. After $6 \mathrm{~h}$, cells were washed with chilled phosphate buffer saline and lysed by sonication in $200 \mu \mathrm{l}$ of lysis buffer (HEPES, $150 \mathrm{mM} \mathrm{NaCl}, \mathrm{MgCl}_{2}, 2 \%$ glycerol, and $1 \mathrm{X}$ protease inhibitor mixture) (Roche). The carbonyl content of the proteins was quantified by reaction with 2,4-Dinitrophenylhydrazine using the OxiELISA Kit according to the manufacturer's instructions (Cell Bio Labs, San Diego, CA, USA).

Statistical analysis. All quantitative assays were analyzed using Prism 5.0 (GraphPad software, La Jolla, CA, USA) with one-way analysis of variance followed by Newman-Keuls multiple comparison post-tests. All values were expressed as mean \pm S.E.M. of at least three measurements from at least two donors, unless otherwise specified. Differences with a probability value of $P<0.05$ were considered significant.

\section{Conflict of Interest}

The authors declare no conflict of interest.

Acknowledgements. This work was supported in part by R01 NS070896-01 from the National Institute of Neurological Disorders and Stroke to VL and AG, and R01 NS48837 to AG. The project entitled 'Laboratory of Developmental Biology' was supported by NIH Award Number 5R24HD0008836 from the Eunice Kennedy Shriver National Institute of Child Health \& Human Development. The content does not necessarily represent the official views of the Eunice Kennedy Shriver National Institute of Child Health and Human Development or of the $\mathrm{NIH}$.

1. Minino AM, Murphy SL, Xu J, Kochanek KD. Deaths: final data for 2008. Natl Vital Stat Rep 2011; 59: 1-126.

2. Aksenova MV, Aksenov MY, Mactutus CF, Booze RM. Cell culture models of oxidative stress and injury in the central nervous system. Curr Neurovasc Res 2005; 2: 73-89.

3. Andersen JK. Oxidative stress in neurodegeneration: cause or consequence? Nat Med 2004; 10 Suppl S18-S25.

4. Valcour VG, Shikuma CM, Watters MR, Sacktor NC. Cognitive impairment in older HIV-1. seropositive individuals: prevalence and potential mechanisms. Aids 2004; 18(Suppl 1): S79-S86.

5. Kozower BD, Christofidou-Solomidou M, Sweitzer TD, Muro S, Buerk DG, Solomides CC et al. Immunotargeting of catalase to the pulmonary endothelium alleviates oxidative stress and reduces acute lung transplantation injury. Nat Biotechnol 2003; 21: 392-398.

6. Halliwell B. Antioxidant defence mechanisms: from the beginning to the end (of the beginning). Free Radic Res 1999; 31: 261-272.

7. Dringen R, Pawlowski PG, Hirrlinger J. Peroxide detoxification by brain cells. J Neurosci Res 2005; 79: 157-165.

8. Desagher S, Glowinski J, Premont J. Astrocytes protect neurons from hydrogen peroxide toxicity. J Neurosci 1996; 16: 2553-2562.

9. Topper JN, Cai J, Falb D, Gimbrone MA Jr. Identification of vascular endothelial genes differentially responsive to fluid mechanical stimuli: cyclooxygenase-2, manganese superoxide dismutase and endothelial cell nitric oxide synthase are selectively upregulated by steady laminar shear stress. Proc Natl Acad Sci USA 1996; 93: 10417-10422.

10. Auerbach JM, Segal M. Peroxide modulation of slow onset potentiation in rat hippocampus. J Neurosci 1997; 17: 8695-8701.

11. Klann E, Thiels $E$. Modulation of protein kinases and protein phosphatases by reactive oxygen species: implications for hippocampal synaptic plasticity. Prog Neuropsychopharmacol Biol Psychiatry 1999; 23: 359-376.

12. Jaffer H, Morris VB, Stewart D, Labhasetwar V. Advances in Stroke Therapy. Drug Deliv Transl Res 2011; 1: 409-419.

13. Tsubokawa T, Jadhav V, Solaroglu I, Shiokawa Y, Konishi Y, Zhang JH. Lecithinized superoxide dismutase improves outcomes and attenuates focal cerebral ischemic injury via antiapoptotic mechanisms in rats. Stroke 2007; 38: 1057-1062.

14. Kim DW, Eum WS, Jang SH, Kim SY, Choi HS, Choi SH et al. Transduced Tat-SOD fusion protein protects against ischemic brain injury. Mol Cells 2005; 19: 88-96.
15. Morris MC, Depollier J, Mery J, Heitz F, Divita G. A peptide carrier for the delivery of biologically active proteins into mammalian cells. Nat Biotechnol 2001; 19: 1173-1176.

16. Veronese FM, Caliceti P, Schiavon O, Sergi M. Polyethylene glycol-superoxide dismutase, a conjugate in search of exploitation. Adv Drug Deliv Rev 2002; 54: 587-606.

17. Francis JW, Ren J, Warren L, Brown RH Jr, Finklestein SP. Postischemic infusion of Cu/Zn superoxide dismutase or SOD:Tet451 reduces cerebral infarction following focal ischemia/reperfusion in rats. Exp Neurol 1997; 146: 435-443.

18. Reddy MK, Labhasetwar V. Nanoparticle-mediated delivery of superoxide dismutase to the brain: an effective strategy to reduce ischemia-reperfusion injury. FASEB J 2009; 23: 1384-1395.

19. Davda J, Labhasetwar V. Characterization of nanoparticle uptake by endothelial cells. Int $J$ Pharm 2002; 233: 51-59.

20. Gaspar T, Katakam P, Snipes JA, Kis B, Domoki F, Bari F et al. Delayed neurona preconditioning by NS1619 is independent of calcium activated potassium channels. J Neurochem 2008; 105: 1115-1128.

21. Hyslop PA, Zhang Z, Pearson DV, Phebus LA. Measurement of striatal $\mathrm{H}_{2} \mathrm{O}_{2}$ by microdialysis following global forebrain ischemia and reperfusion in the rat: correlation with the cytotoxic potential of $\mathrm{H}_{2} \mathrm{O}_{2}$ in vitro. Brain Res 1995; 671: 181-186.

22. de la Monte SM, Neely TR, Cannon J, Wands JR. Oxidative stress and hypoxia-like injury cause Alzheimer-type molecular abnormalities in central nervous system neurons. Cell Mol Life Sci 2000; 57: 1471-1481.

23. Haskew-Layton RE, Payappilly JB, Smirnova NA, Ma TC, Chan KK, Murphy TH et al. Controlled enzymatic production of astrocytic hydrogen peroxide protects neurons from oxidative stress via an Nrf2-independent pathway. Proc Natl Acad Sci USA 2010; 107: $17385-17390$

24. Shih AY, Johnson DA, Wong G, Kraft AD, Jiang L, Erb H et al. Coordinate regulation of glutathione biosynthesis and release by Nrf2-expressing glia potently protects neurons from oxidative stress. J Neurosci 2003; 23: 3394-3406.

25. Luo D, Saltzman WM. Synthetic DNA delivery systems. Nat Biotechnol 2000; 18: 33-37. 26. Anderson WF. Human gene therapy. Nature 1998; 392(6679 Suppl): 25-30.

27. Check E. Second cancer case halts gene-therapy trials. Nature 2003; 421: 305

28. Marwick C. FDA halts gene therapy trials after leukaemia case in France. BMJ 2003; 326: 181.

29. Lutsep HL, Clark WM. Current status of neuroprotective agents in the treatment of acute ischemic stroke. Curr Neurol Neurosci Rep 2001; 1: 13-18.

30. Claiborne A, Fridovich I. Purification of the o-dianisidine peroxidase from Escherichia coli B. Physicochemical characterization and analysis of its dual catalatic and peroxidatic activities. J Biol Chem 1979; 254: 4245-4252.

31. Kirkman HN, Gaetani GF. Catalase: a tetrameric enzyme with four tightly bound molecules of NADPH. Proc Natl Acad Sci USA 1984; 81: 4343-4347.

32. Aebi H. Catalase in vitro. Methods Enzymol 1984; 105: 121-126.

33. Bal-Price A, Brown GC. Inflammatory neurodegeneration mediated by nitric oxide from activated glia-inhibiting neuronal respiration, causing glutamate release and excitotoxicity. J Neurosci 2001; 21: 6480-6491.

34. Panyam J, Zhou WZ, Prabha S, Sahoo SK, Labhasetwar V. Rapid endo-Iysosomal escape of poly(DL-lactide-co-glycolide) nanoparticles: implications for drug and gene delivery. Faseb J 2002; 16: 1217-1226.

35. Putnam D, Gentry CA, Pack DW, Langer R. Polymer-based gene delivery with low cytotoxicity by a unique balance of side-chain termini. Proc Natl Acad Sci USA 2001; 98: 1200-1205.

36. Rao KS, Ghorpade A, Labhasetwar V. Targeting anti-HIV drugs to the CNS. Expert Opin Drug Deliv 2009; 6: 771-784.

37. Ashutosh Chao C, Borgmann K, Brew K, Ghorpade A. Tissue inhibitor of metalloproteinases-1 protects human neurons from staurosporine and HIV-1-induced apoptosis: mechanisms and relevance to HIV-1-associated dementia. Cell Death Dis 2012; 3: e332.

38. Almeida A, Delgado-Esteban M, Bolanos JP, Medina JM. Oxygen and glucose deprivation induces mitochondrial dysfunction and oxidative stress in neurones but not in astrocytes in primary culture. J Neurochem 2002; 81: 207-217.

39. Reddy DS, Reddy BK, Gunasekhar KR, Reddy PS. Nanostructured Cd(1-x)Mn(x)S films for spintronics and optoelectronic device applications: synthesis and characterization. J Nanosci Nanotechnol 2008; 8: 6487-6490.

40. Deshpande M, Zheng J, Borgmann K, Persidsky R, Wu L, Schellpeper C et al. Role of activated astrocytes in neuronal damage: potential links to HIV-1-associated dementia. Neurotox Res 2005; 7: 183-192.

41. Manthorpe M, Fagnani R, Skaper SD, Varon S. An automated colorimetric microassay for neuronotrophic factors. Brain Res 1986; 390: 191-198.

(c) (i) $\odot$ Cell Death and Disease is an open-access journal published by Nature Publishing Group. This work is licensed under a Creative Commons Attribution-NonCommercialNoDerivs 3.0 Unported License. To view a copy of this license, visit http://creativecommons.org/licenses/by-nc-nd/3.0/ 